\title{
Caves and the Surrounding Archaeological Assemblages in Talakona Region, Andhra Pradesh
}

\author{
Dr. T. Babji Reddy \\ Senior Academic Fellow, Indian Council of Historical Research (ICHR), New Delhi. Email: \\ t.babjireddy@gmail.com
}

\begin{abstract}
Caves have been using as natural dwellings from prehistoric times to the present. It is known fact that the worldwide Archaeologists and Anthropologists were collected the most important cultural and physical remains of early human beings from the caves. The present paper discusses about the caves and its surrounding archaeological assemblages found inside and around the caves based on the explorations conducted in Talakona forest region (a part in Tirumala/Seshachalam hills) in Andhra Pradesh. Talakona region have several evidences of prehistoric and proto-historic period. The available evidences such as Palaeolithic stone tools (hand axes, cleavers, flakes etc.), rock art, megalithic burials and historic temples suggest that this region has great continuity from the past. The present paper discusses the human continuity based on the archaeological evidences available from the caves and its surrounding environment.
\end{abstract}

Keywords: Caves, Dolmens, Rock art, inscriptions

\section{INTRODUCTION}

Caves are hollow places appears in the hills, hillocks or rock mounds. The exploration and scientific study of caves are known 'Speleology'. Caves are two types they are natural and artificial. The natural caves are formed due to weathering and the artificial caves are excavated by the human for mainly two purposes like dwellings or religious fervours. It is known fact that the worldwide Archaeologists and Anthropologists were collected the most important cultural and physical remains of early human beings from the caves. In the human evolutionary history caves are the primary dwellings for the past communities because at the beginning of the human evolution they do not have the knowledge regarding the construction of house. Based on the available evidences from caves around the globe, the Pre-historians suggested that the human in the past mostly existed in the caves.

The pre-historians mainly focus on caves because the caves are the store houses for containing well preserved pre and proto-historic and religious archaeological remains. The worldwide important fossil evidences of understanding human evolution were found in the caves. For example Homo naledi- named as Neo was found in the Lesedi Chamber of the Rising Star Cave in northwest of Johannesburg in South Africa. The oldest (approximately 4 million old) fossil remains of Australopithecus africanus, Australopithecus prometheus, Homo gautengensis, Paranthropus robustus and homo habillus was found in Swartkrans and kromadrai-a lime stone caves near Johannes berg in South Africa. This region is also known as 'the Cradle of Humankind".

(C) AesthetixMS 2018. This Open Access article is published under a Creative Commons Attribution Non-Commercial 4.0 International License (http://creativecommons.org/licenses/by-nc/4.0/), which permits non-commercial re-use, distribution, and reproduction in any medium, provided the original work is properly cited. For citation use the DOI. For commercial re-use, please contact editor@chitrolekha.com 
This region designated a UNESCO World Heritage site in 1999 due to its important archaeological remains. The other caves like Choukoutien-a cave near Peking in China, for an Upper and Middle Palaeolithic culture, Wonderwork cave at Northern Cape Province in South Africa (2 million years) are the few examples for the caves which were provided earliest human fossils.

The caves are also the places of artistic expressions of early human. The most earliest and wonderful beatific, aesthetic and imaginative paintings were found around the world in the caves. The well-known caves of earliest cave paintings are Lascaux (a cave in France and it is UNESCO World Heritage Site), Yellabidde caves in western Australia, Altamira caves in Spain (around 35,60o years paintings), Blombos caves in South Africa (73, ooo old rock art), Bhimbetka caves (290,000-700,000 BCE- it is UNESCO world heritage site) and Dharaki-Chattan rock shelters in Madya Pradesh and Kurnool caves in Andhra Pradesh in India; Sulawesi caves in Indonesia; Chauvet caves in France. Several rock shelters around the world were also identified as the ancient abodes of prehistoric humans.

India has several natural caves and rock shelters which are having great evidences belong to prehistoric, historic and religious cultures. In these caves, the archaeologists identified deferent artefacts belongs to different cultural periods. The caves which are having the evidences of early human existence in India are Borra Caves (middle Palaeolithic culture dates between 30,000 and 50,000 years) located in Anatagiri Hills of the Araku valley in Andhra Pradesh; Belum caves in Karnool (4,500 BC remnant vessels were found); Mawsmai caves located near Cherrapunji in Meghalaya are the few examples for naturally formed caves.

\section{Contemporary Cave dwellers (Cliff Dwellings/cave homes) around the world}

Caves showing proofs of inhabitations are widely distributed around the world. The present cave dwellers are the live examples for understanding the habit of dwelling in the caves which have been continued from the prehistoric era. Even in the present modern day several people around the globe still live in caves and these caves are using as permanent houses by modifying with wood, stones and clay. Sometimes, the caves were also used as graves for preserving human dead and performing its associated ceremonies.

The Cave dwellings are common in Shaanxi and Shanxi of northern China where they serve as homes for more than 40 million people have been using this cave houses for centuries. In Tunisia; the Berber residents in Matmata village live in traditional underground 'troglodyte' dwellings; Bamiyan Buddha caves in Hazarajat region of central Afghanistan is famous for two gigantic statues of 175 feet world highest standing Buddhas carved into the side of a cliff during 6th-7th century C.E (which were destroyed by Taliban in 2001). The cave dwellings at Bamiyan at one time housed thousands of Bhiddhist monks. Later the civilians made their homes in the caves. Many of the caves have remains of painted frescos; The 'Sassi di Matera' is cave dwellings which are located in southern Italy are originate from a prehistoric settlement, and are among the first human settlements in Italy. Many of the houses, which are dug into the tufa rock, are really only caverns, and the streets in some parts of the Sassi often are located on the rooftops of other houses. In the 1950s, the government forcefully relocated most of the population of the Sassi to areas of the developing modern city. However, some people continued to live in the Sassi just as their ancestors of 9,00o years ago; Mesa Verde, located in south-western Colorado near the community of Cortez, is home to the famous cliff dwellings of the ancient Anasazi people. It may be the most significant archaeological preserve of Native American culture in the United States. 
In the $12^{\text {th }}$ century, the Anasazi start building houses in shallow caves and under rock overhangs along the canyon walls. The ruins of dwellings remain almost perfectly still preserved.

The Bandiagara (UNESCO world heritage site) is a sandstone cliff in the Dogon country of Mali. These cliffs were ancient cave homes of the Tellem people. They built dozens of villages along the cliffs above the caves. The Dogon-villagers built their homes in the caves, with their traditional architecture of clay. Kandovan is an ancient 800 years old village in the province of East Azarbaijan, nearer to the city of Tabriz in Iran. The homes at Kandovan have dug their cave homes in cone-shaped, naturally formed volcanic ash formations of gigantic termite hills for two to four storeys in height. Goreme and Uçhisar towns in Cappadocia are the best examples of

castled cave dwellings in Turkey. Some of the people in Ravalpindi in Pakistan while going to Islamabad from Dhoke Ratta the people using the cave dwellings even in this modern day.

There are several other caves which attracting people as tourist spots. These are like Mogao Caves (366 AD) and Dunhuang cave in China, Hercules cave (6ooo BC Neolithic evidences) in Moracco; Huto and Kamarband Caves(70oo BCE) in Iran; Kara-kamar caves in Uzbekistan; Jerf al-Ajla cave in Syria; Maijishan Grottoes caves ( Buddhist) in China.

\section{Caves of monasteries and Religious fervours in India}

The natural as well as human excavated caves are used for monasteries and associated religious fervours. The world famous Buddhist monastic caves are Ajanta Caves in Maharastra (These series of caves were excavated during different periods circa $2^{\text {nd }}$ century B.C to 600 A.D., according to the necessity); Ellora Caves located in Maharastra are a stone-hewn monastic monolithic chiselled cave temples belongs to 600-1000 CE period featuring Buddist, Hindu and Jain monuments and artwork; Elephanta caves located near Mumbai date back to 450 and 750 AD; Amarnath Caves in Jammu \& Kashmir; Tabo caves in Himachal Pradesh; Barabar caves of Gaya in Bihar; Patal Bhuvaneswar cave in Uttarakhand; Jogimara Cave (found $1^{\text {st }}$ century BC paintings and Brahmi inscriptions) in Chattisgarh Badami caves in Karnataka; Udayagiri and Khandagiri caves in Orissa; Undavalli and Mogalarajapuram Caves in Andhra Pradesh; Varaha and Mahishasura Mardhini cave temples in Mahabalipuram, Tamilnadu (UNESCO world heritage site) are few caves for religious importance.

Even in the present society at several regions across the world, the people celebrate several rituals and local ceremonies at caves. Caves also continue to be sacred and important places in local, regional and even international geography (Fienberg M.J. 2016) and therefore scholars are obliged to protect and respect the present as well as the past by working with ritual specialists while developing research plan.

\section{THE TALAKONA FOREST REGION}

Talakona forest region is one of the parts of Eastern Ghats located in Seshachalam hills (also known as Tirumala hills or Palakondalu) at a distance of about $65 \mathrm{~km}$ from Tirupati in Chittoor district, Andhra Pradesh. There is a perennial waterfall known as siddhodhara teertham which commonly called Talakona water fall which is about $60.96 \mathrm{~m}$ height. There is ancient shrine of Siddheswara in the valley and the devotees gather here in every day. The unique and important flora of the region is red sandal. There are so many rare medicinal plant species found in Talakona forest which are used by the local people for both human and animal medicinal preparations. According to the local herbalists the rare herbal plants like kodipodhugu chettu (these plants 
moves like hen and chick), nagabhutham chettu (cobra like plant) and sanjeevi chettu (this magical herb mentioned in Ramayana) are found in this forest. The fauna of this region is very rich with various species of animals belonging to class mammalian in particular. Geological formation of this area consists of Archeans, Eparcheans, unconformity puranas and quaternary deposits which are considered to be the ancient most land formation in the world. The Talakona valley consist a number of seasonal and perennial water falls, lakes and hill streams. The vegetation of the valley belongs to the dry deciduous scrub savannah and tropical thorny types which consist of a variety of floral species. The annual normal rainfall is $934 \mathrm{mms}$. The minimum, maximum and mean temperature of this region is $12.5^{\circ} \mathrm{c}, 44.2^{\circ} \mathrm{c}$ and $36.5^{\circ}$ respectively. The prehistoric tools like different types of hand axes, cleavers and flake tools are identified in the Talakona forest along with Megalithic dolmens and Neolithic ring stones.

\section{CAVES IN TALAKONA FOREST REGION}

Several caves and rock shelters are identified in Talakona forest region. The names of the caves and its archaeological importance have explained as follows.

\section{Appaswamy caves in Talakona}

Appaswamy caves are located near to Talakona water fall in Nerabylu village of Yerravaripalem mandal in Chittoor district, Andhra Pradesh. There are five naturally formed caves laid side by side and consisted several types of evidences for understanding the continuity of the human subsistence from the past. These caves are located beside Talakona stream and very nearer to the water fall. The first cave from the water fall consisted several stone hewn sculptures of Hindu gods like Hanuman, Sivalinga, Vinayaka; religious fauna like elephant, cobras and lamp keeping holes (dheegoodu) are chiselled on the surfaces of the caves.

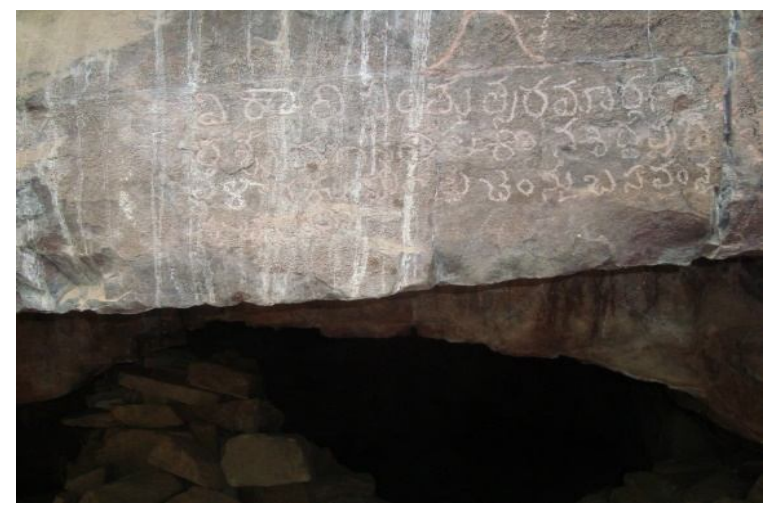

Figure 1: Inscription in Telugu language at Appaswamy cave in Talakona

The inscription in Telugu language is identified in another cave. This cave was shaped as temple by constructing stones wall. According to this inscription, the Sivaling in this cave was installed in the Telugu Vikari year, Margasira month, $10^{\text {th }}$ day of shuddha paksha (Monday) in 1719. At present the temple is ruined and the Sivaling, Nandhi and bronze bell was stolen by the treasure hunters.

The engraved oxen and some other symbols and animals are identified on hilltop of Talakona at Rudragalatheertham at a distance of $6 \mathrm{~km}$ from Appaswamy caves. The mortars were hewed on rock surfaces are observed at nearer to some water sources in Talakona forest. The 
stone artefacts of the early humans such as Pebbles, Hand Axes, flakes and cores are identified along the sides of streams. The stone tools found around the caves are the chief characteristic tools of Palaeolithic period.

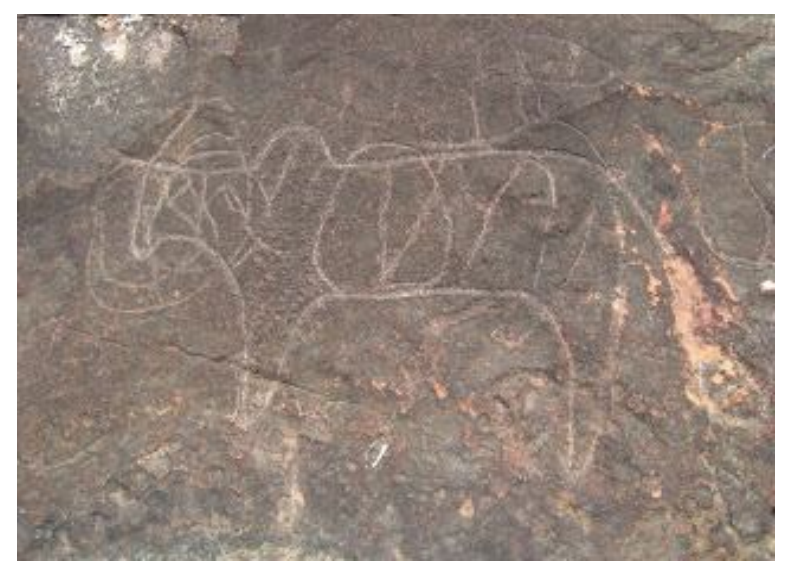

Figure2: Engraved oxen on rock surface at Rudragalatheertham in Talakona forest

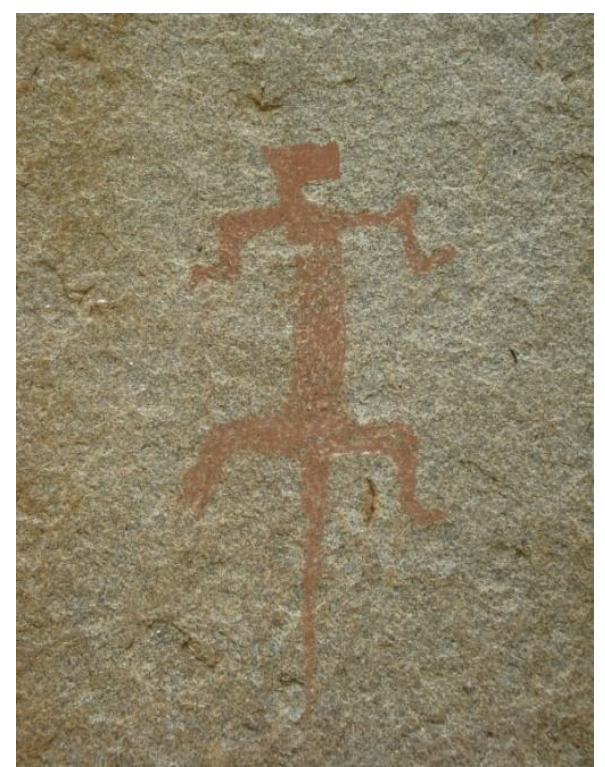

Figure 3: The red ochre climbing monitor lizard at jangamollakonda near chittecherla

\section{Jangamolla konda rock shelters:}

It is located ( $13^{\circ} 39^{\prime} 32^{\prime \prime} \mathrm{NL}$ and $\left.79^{\circ} 10^{\prime} 47^{\prime \prime} \mathrm{EL}\right) 2 \mathrm{~km}$ towards the east from Nagari village (Chittecherla) and $4 \mathrm{~km}$ towards east from Bhakarapeta. Several rock shelters found around in Jangamolla konda locality which consisting few evidences of human continuity from the past. Among the rock shelters, the rock paintings were identified in two rock shelters namely Jangamalla gundlu and akkagarla gavi. These two rock shelters lay side by side at the distance of 100 meters and both two shelters are having red ochre and white pigmented graffities. The 'jangamalla gundlu' is a huge boulder measures approximately 25 meters height. The red ochre figure of the climbing monitor lizard (veranus) locally known udumu was drawn on east side at the height of 3.5 meter from the ground. The white pictures of the horse riders are also drawn in 
west side of this same shelter but these are faded due to rain wash-off or other climatic conditions. During the Palegar times the stone walls are constructed around this shelter and used as their residences. The mortars are also dug-out inside the rock shelter for grinding cooking ingredients.

Another rock art shelter namely Akkagarla gavi is also having red and white ochre figures. The conch shaped oval lines drawn one upon one for five ovals in red ochre. Beside these circles the standing horse and standing human figure was drawn with white pigment. Several other figures are also drawn on this cave but which are partially withered and unable to interpret the actual shape.

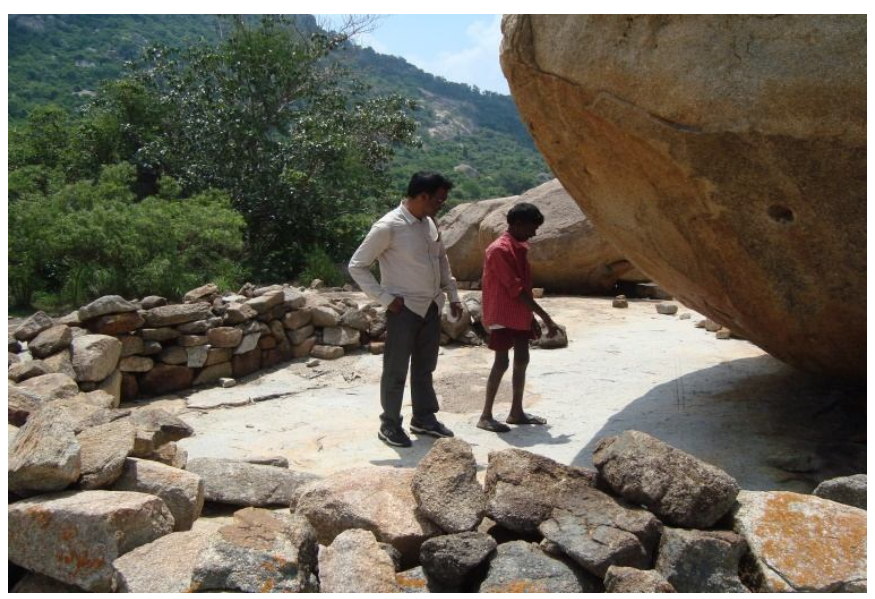

Figure 4: The villager showing inscription to the author at dhonabanda near chittecherla

The inscription in Telugu language near the engraved shape like flagpole with sun in one side and moon at other side are also identified on the rock surface at dhona banda at the distance of 500 meters from this rock art sites. The inscription is fully paled but a few letters are readable.

The surrounding hillocks are having several natural water catchments locally known 'dhona' in which the water available even in drought conditions. Due to availability of water in all seasons and accessibility of forest resources around these water bodies, the early human used these shelters for their survival.

\section{Vasiketamma Gavi in Yerravari Palem}

This cave is located at a distance of $1.5 \mathrm{~km}$ from Yerravari Palem village in the hillock locally known vasiketammakonda. The natural water catchment known Bandakonda Dhona is located nearer to this cave. In this natural catchment, water available entire year even in drought conditions. A few artefacts of the early man have identified at the nearest agricultural fields. 


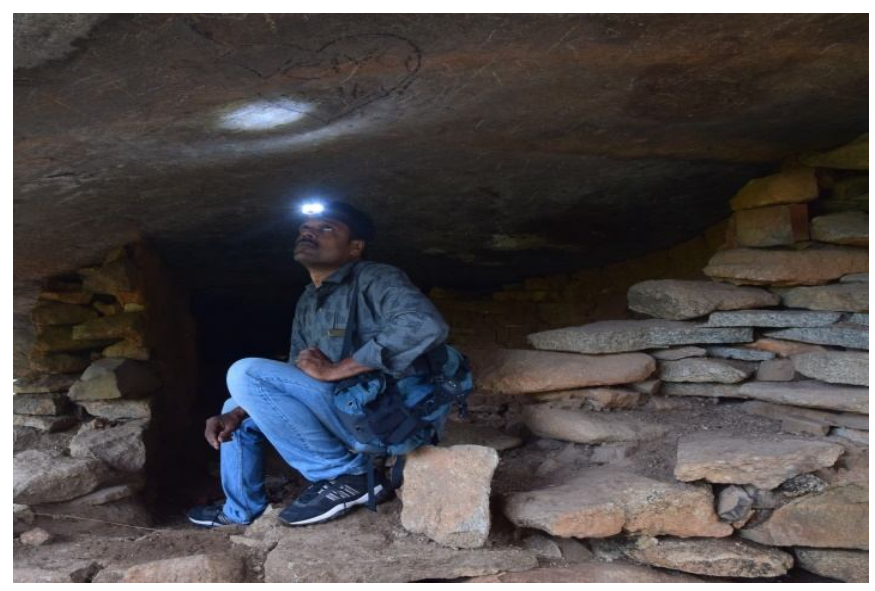

Figure 5: The author searching for evidences inside the cave

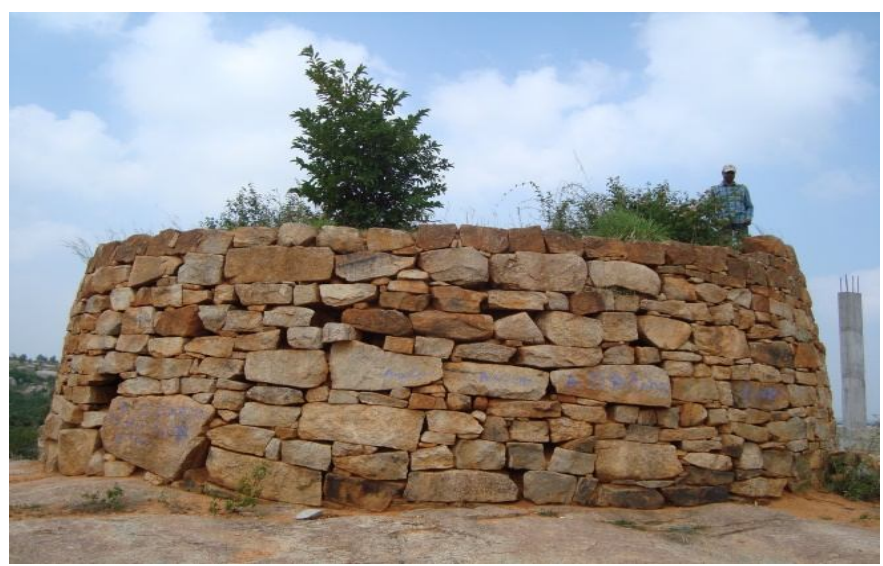

Figure 6: Stone made circular ruined mono tower near Yerravari Palem

\section{Gaddamvari Palli}

This cave is located at distance of $2 \mathrm{~km}$ east to Gaddamvari Palli village in Yerravaripalem mandal. The upper Palaeolithic tools were identified nearer to this cave. The Megalithic burials such as dolmens, cist and ruined cairn burials are identified at a distance of $3 \mathrm{~km}$ from these caves on the hillock locally called Vekatapuram gutta nearer to Nerabailu village. The ancient temple of Lord Balaji is also located on this hillock beside these megalithic burials.

At a distance of $2 \mathrm{~km}$ from this cave a ruined flat cone template shaped turrets/towers (locally called buruju) were constructed with mud and stone are identified near to Matlivari Palli Palem. This tower was constructed on the top of huge stone boulder.

\section{Kothulagutta Gavi}

This cave is identified in a hillock locally known Kothulagutta beside the stream locally known talakoneru at a distance of $2 \mathrm{~km}$ from O.S.Bandakada Palli of Yellamandha Panchayat in Yerravari Palem Mandal. Three caves are identified in this hillock but one cave is larger than other caves. 
The Megalithic burials such as dolmens are located at Gadimadugu beside Talakoneru (stream) near Aravavandla Palli at a distance of $3 \mathrm{~km}$ towards west to this cave. Neolithic ring stones are also identified in the agricultural fields nearer to this cave.

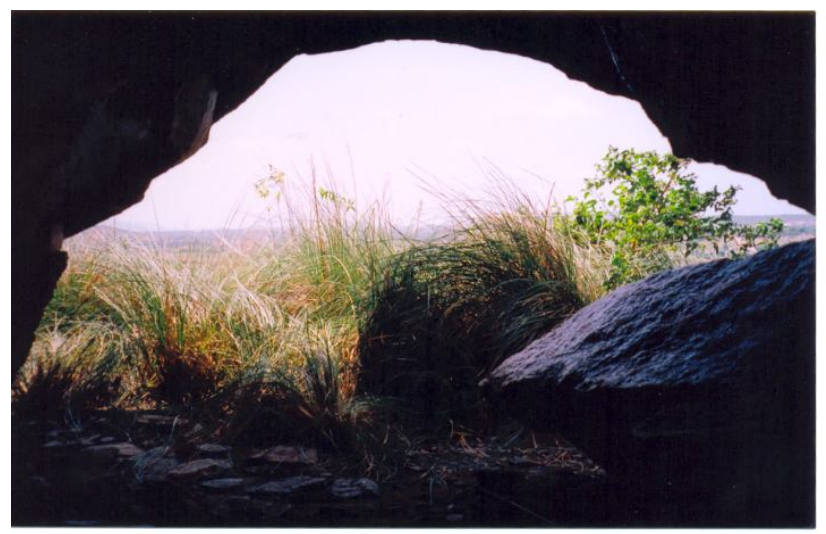

Figure 7: View from inside of the cave at Kothulagutta

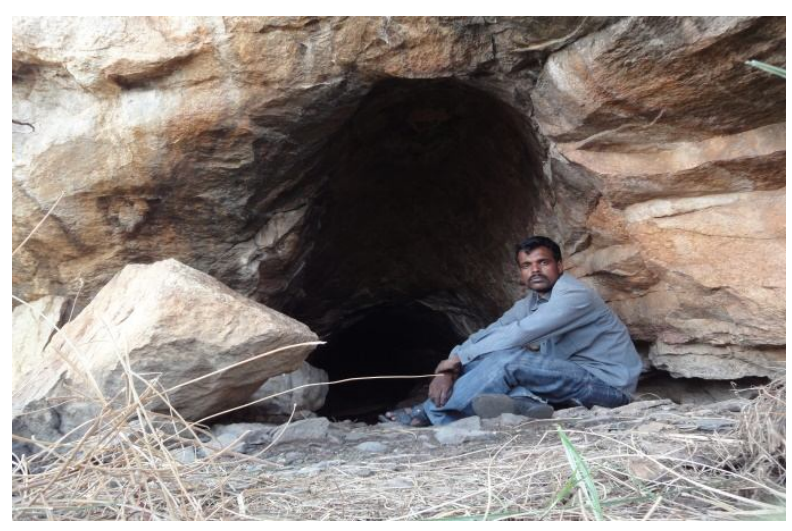

Figure 8: The author at the front of the cave

The inscription in Telugu language is also identified near to this cave on a rock surface adjacent to a tank namely Ramadasuchuruvu near V.R.Agraharam. The inscription reveals about the excavation of the tank. According to this inscription the tank was excavated during Vijayanagara period.

The stone artefacts such as miniature Hand axes, Flake tools and cores are also found around this cave at the distance of $100 \mathrm{~m}$ and these are the chief characteristic tools of Paleolithic period.

\section{Dhoggalakonda Gavi}

This cave is located in a hillock locally known Dhoggalakonda in Thalapula village in Piler mandal. Several flake tools and hand axes are identified in agricultural fields and at streams near to this cave. The red ochre rock paintings identified at jandla village at a distance of $6 \mathrm{~km}$ from this cave. The red ochre circles and semi-circles were identified on 'Yerukula gundu in the hillock locally called Jurapothula gutta near to Jandla village. 


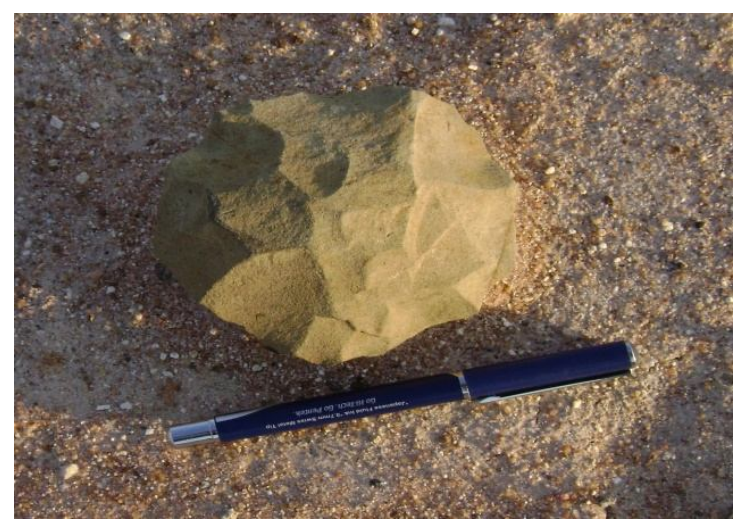

Figure 9: Stone artefact found nearer to the cave

\section{Thalabodu gavi}

This cave is located $2 \mathrm{~km}$ towards north-west from O.S.Bandakada Palli in Yellamandha revenue in Yerravari Palem Mandal. The seasonal water stream namely Arlapentavanka flows very close to this cave. Some of the old porcupine and tiger stone traps are observed in front of this cave. There are two other caves namely Nallakanam gavi and Cheekakona gavi are located nearer to this cave.

The megalithic art is identified in a rock shelter namely Yanadhodigundu at a distance of 1 $\mathrm{km}$ from this cave. The figures were drawn with white pigment on the ceilings of the rock shelter.

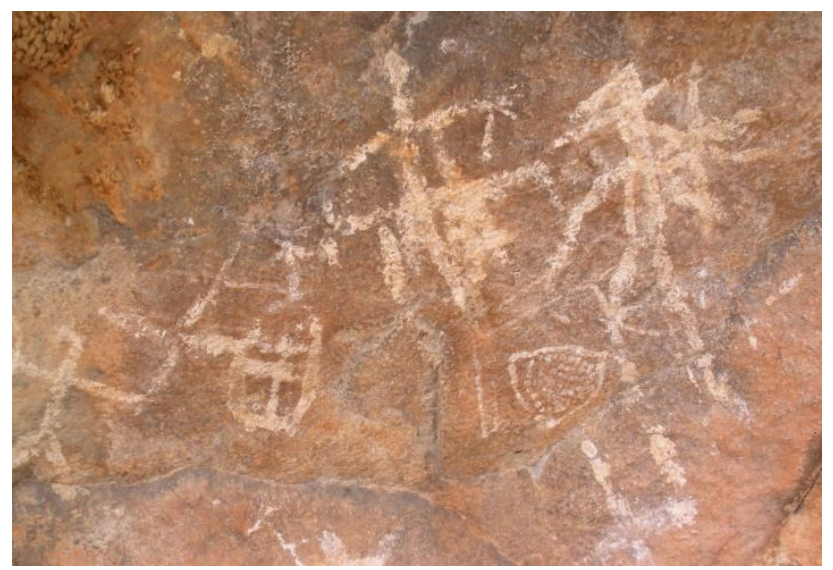

Figure 10: Megalithic art at Yanadhodi gundu near to Thalabodu Gavi: figures depicting battle scene

The figures are depicting as a horse rider holding a sword with one hand and shield with another hand. The other depiction shows a warrior on the ground in a moving posture holding a sword with one hand and shield with another hand. One of the faded graffiti shows a battle scene in which a group of warriors fights each other with the swords and shields riding on horses. A circle-with-trident (locally known as Peeru) and some unknown geometric symbols are also found. A unique depiction showing a man wearing a bird headed mask with prominent beak. Some of the figures looks like the symbols which are uses by the local aboriginals for knowing the future and missing animals or other things (this system is locally known saginam or prashna- in this indigenous knowing method, the practicener draws some vertical lines on a long straight line and estimates by calculating the lines). The unique features of the rock art in the present discussing site is the figures are not depicting head, fingers and other important external organs of the body. The shapes of human and animals were drawn with lines only. 


\section{CONCLUSION}

The caves in Talakona region shows great evidences pertaining to early human existence. The availability of prehistoric stone artefacts, rock art and historic inscriptions nearer to these caves reveals that the prehistoric population used these caves for their shelters. The rock paintings of this area are clues for understanding the social, economic and religious life of early human. The available evidences suggest Talakona region has great continuity of human subsistence from the past to the present.

\section{Acknowledgements}

The author is very thankful to Indian Council of Historical Research (ICHR) for providing financial assistance as Senior Academic Fellowship for studying prehistoric rock paintings in Tirumala hill region in Andhra Pradesh.

\section{REFERENCES}

Benoy K. B \& Milo C. B. 2005. The Ajanta Caves: Ancient Paintings of Buddhist India. Thames \& Hudson Publishers.

Carly Monks et al. 2016.Pleistocene occupation of Yellabidde Cave in the northern Swan Coastal Plain, southwestern Australia. Australian Archaeology. 82:3, 275-279, DOI: 10.108o/03122417.2016.1244216 (https://doi.org/10.108o/03122417.2016.1244216).

Dowd M.2015.The Archaeology of Caves in Ireland. Oxbow Books. USA.

Feinberg M.J. 2016. Caves and Karst Across Time. Geological Society of America Vol-516.pp.197-210.

Henshilwood C.S et al. 2018. An Abstract drawing from the 7300o-year old levels at Blombos cave, South Africa. Nature. 12 September. pp.1-4.

http://www.washington.edu/news/2017/05/o9/early-human-fossils-found-in-south-african-cave-system/.

John Hawks et all.2017. New fossil remains of Homo naledi from the Lesedi Chamber, South Africa.Elife.article24232. (https://elifesciences.org/articles/24232).

Misra.V.N. 2001. Prehistoric human colonization of India. J. Biosci. Vol. 26, No. 4,Suppl. pp.491-531. Indian Academy of Sciences.

Murthy.M.L.K. 1966. Stone Age Cultures of Chittoor District. Andhra Pradesh. Ph.D. dissertation, Pune University.

Ramabrahmam.V. 1995. Evidence of Megalithic art in Chittoor district. Proceedings of the XIX Andhra Pradesh History Congress, Anantapur. pp.22-24.

Ramabrahmam.V. 2003. Mallaiahpalle-unique Megalithic Rock art site in Chittoor district. Proceedings of the XXVII Andhra Pradesh History Congress, Tirupati. pp.21-22.

Reddy T.B \& Reddy V. M. 2013. Discovery of new Rock Art site in Talakona Valley in Chittoor District, Andhra Pradesh. Paripex-Indian Journal of Research. Vol:2, Issue : 1.pp.4-6.

Reddy T.B.2015. Pre and proto historic evidences of human subsistence in the Talakona valley. Golden Research Thoughts. Vol4(10).pp.1-9.

Reddy. T.B. 2012. Resources and Livelihood: Knowledge, Traditions and Practices. Lambert Publishing Company. Germany. 
63 | Caves and the Surrounding Archaeological Assemblages in Talakona Region, Andhra Pradesh

Srikantia S.V. 2013. Robert Bruce Foote: His Contribution to the Geology of Karnataka, the Southern Peninsular India and Indian Prehistory. Jour.Geol. Soc.India.Vol.81, Jan. 2013.pp.17-26.

Walter F.J. 1910. The cave dwellings of the old and new worlds. American Anthropologist (N. S., 12). pp.390416. 